\title{
The Pharmacognostic Study of Leaves of Caesalpinia crista (Linn.) and Leucaena leucocephala (Lam.)
}

\author{
Radhika Rani $^{1 *}$, Tahira Begum ${ }^{2}$ \\ ${ }^{1}$ Department of Botany, Samrat Prithviraj Chauhan, Government College Ajmer, Rajasthan, India \\ ${ }^{2}$ Department of Botany, Samrat Prithviraj Chauhan, Government College Ajmer, Rajasthan, India
}

Available online at: www.isroset.org

Received: 20/Mar/2019, Accepted: 11/Apr/2019, Online: 30/Apr/2019

\begin{abstract}
Medicinal plants Caesalpinia crista (Linn.) and Leucaena leucocephala (Lam.) belongs to the family Fabaceae. Parts (root, stem, leaves and seeds) of both the plant species have been used in different systems of traditional medication of human ailments. Both species contains various bioactive components which have been used as anti-asthmatic, anti-diabetic, anti-inflammatory, anti-oxidant, anti-bacterial etc. The present paper attempts to evaluate the pharmacognostic characteristics in terms of macro and micro-morphological characters, and quantitative profiles of the leaves of C. crista and L. leucocephala. Pharmacognostic parameters of the leaves will assist in identification, authentication, and standardization for quality, purity and control adulteration of the crude drug.
\end{abstract}

Keywords: Macroscopy, Microscopy, Organoleptic Parameters, Quantitative Determination.

\section{INTRODUCTION}

Medicinal plants play an important role in human health as herbal medicines all over the world. After decades of serious obsession with the modern medicinal system, people have started looking at the ancient healing systems like Ayurveda, Siddha and Unani. This is because of the adverse effects associated with synthetic drugs [1]. According to the WHO, the macroscopical and microscopical description of a medicinal plant is the first step towards establishing the identity and degree of their purity [2]. Caesalpinia crista (Linn.) (Synonyms Caesalpinia bonduc (L.) Roxb, Syn. Caesalpinia bonducella (L.) Fleming [3]) is commonly known as Katakaranja in Hindi and Fever Nut in English. It is a large, scandent prickly shrub which is widely distributed in tropical regions of the world especially in India and Sri Lanka. It is a very valuable medicinal plant because of the presence of various bioactive components utilized in traditional system of medicine [4][5]. The juice of the leaves is antihelminthic; used in elephantiasis, small pox and liver disorders. In Malaya the young leaves are used in intermittent fevers and for expelling intestinal worms. In Ceylon, they are applied for toothache [6]. Leucaena leucocephala (Lam.) is a thornless medium sized fastgrowing tropical tree and indigenous to Southern Mexico and Northern Central America and now in many tropical and sub-tropical regions it has grown widely. White lead tree, White popinac, Jumbay and wild Tamarind are the common names. Kubabul or subabul is the popular name in India. Due to the outstanding multiple uses it was promoted as a "miracle tree". It has been used to cure various ailments because of its medicinal values and also used to control soil erosion, fuel wood, timber, fodder, green manure, etc.[7]. It has medicinal properties ranging from control of stomach diseases to contraception and abortion [8][9]. The present studies were carried out to determine the macro and micromorphological characters, and quantitative parameters to evaluate pharmacognostic properties of the leaves of $\boldsymbol{C}$. crista and L. leucocephala.

\section{MATERIAL AND METHODS}

\subsection{Collection and Authentication of Botanical Material} Fresh leaves of $\boldsymbol{C}$. crista and $\boldsymbol{L}$. leucocephala were collected from the local area around Ajmer, Rajasthan (India) and authenticated by the taxonomist Dr. C.B. Gena. A herbarium specimen of each has been deposited at the Department of Botany, Samrat Prithviraj Chauhan Government College Ajmer.

\subsection{Preparation for Examination}

Collected fresh leaves of plants $\boldsymbol{C}$. crista and $\boldsymbol{L}$. leucocephala were cleaned thoroughly to remove adhering foreign bodies and other contaminants. Microscopic evaluation was done by using standard methods.

\subsection{Chemicals}

The chemicals like trichloroacetic acid, phenol, lactic acid, safranin, glycerine, distilled water etc. were used. The entire chemical, used in experiments were of analytical grade.

\subsection{Macroscopic Examination}

The fresh leaves of both plants were evaluated for various organoleptic parameters such as the shape, size, colour, 
margin, texture, apex, presence or absence of petiole, phyllotaxy etc.

\subsection{Microscopic Examination}

The histological features such as structure of epidermal cells, structure, distribution and type of stomata, structure and distribution of trichomes on the fresh leaves have been analyzed.

\subsection{Quantitative microscopy}

For the quantitative microscopy the number of epidermal cell, number of stomata and stomatal index for both abaxial and adaxial surfaces of the leaves were determined according to method of Mohan Ram and Nayyar [10] with slight modifications. Entire fresh leaves were soaked in the mixture of trichloroacetic acid and phenol in the proportion of 2:1 for $15-60 \mathrm{~min}$ at $60^{\circ} \mathrm{C}$ temperature. The cleared leaves were flooded with pure lactic acid and kept at $60^{\circ} \mathrm{C}$ temperature for various time periods and were then washed with water. Cleared leaves were stained with safranin, mounted with glycerin and observed under compound microscope. The quantitative estimations were carried out by using methods of Salisbury (1927); [11]; [12]; [13]

a) Epidermal cell number: The average number of epidermal cells per square millimeter unit of epidermis is termed as epidermal cell number.

b) Stomatal number: The average number of stomata per square millimeter of epidermis is termed as stomatal number.

c) Stomatal index: The percentage of number of stomata to the total number of epidermal cells (wherein each stomata also is considered to be a single epidermal cell), is termed as stomatal index. The stomatal Index was calculated using the standard formula given below.
Stomatal Index (S.I.) $=\mathrm{S} * 100 / \mathrm{S}+\mathrm{E}$

$\mathrm{S}=$ quantity of stomata per unit area and $\mathrm{E}=$ number of ordinary epidermal cells in the same unit area[14][15].

The quantitative parameters have been subjected to statistical analysis and expressed as Mean \pm SEM.

\section{RESULTS/DISCUSSION}

\subsection{Macromorphology}

The results of the organoleptic and macroscopic examination established that the plant $\boldsymbol{C}$. crista is an extensive climber which branches finely and is grey-brown in color. It is armed with hooked hard yellow prickles. Leaves of plant are pinnately compound with even number of leaflets (paripinnate) and phyllotaxy is opposite/ superposed. The leaflets have dimension $(1 * b) 14.24 \pm 0.24$, terminal leaflets are slightly longer than the lower leaflets, number of leaflets range between $12-18$, each being elliptical/oblong having entire margin with pilose trichomes, the apex is acute/obtuse; the leaflets are dark green on adaxial surface and light green on abaxial surface, glabrous, petiolate (very short); a curved hook is present at the base of each leaflet on abaxial side, the venation is unicostate reticulate.

The results of the organoleptic and macroscopic examination established that the plant L. leucocephala is large erect tree. Leaves of the plant are pinnately compound with even number of leaflets (paripinnate) and phyllotaxy is opposite/ superposed. The leaflets have dimension $(1 * b) 0.86 \pm 0.04$, number of leaflets range between 18-24, petiole absent/ sessile, entire margin, , elliptical, apiculate apex, the color being dark green on adaxial surface and light green on abaxial surface, glabrous, stipulate/ interpetiolar, unicostate reticulate venation. Raised glands are present at the base of each leaf.
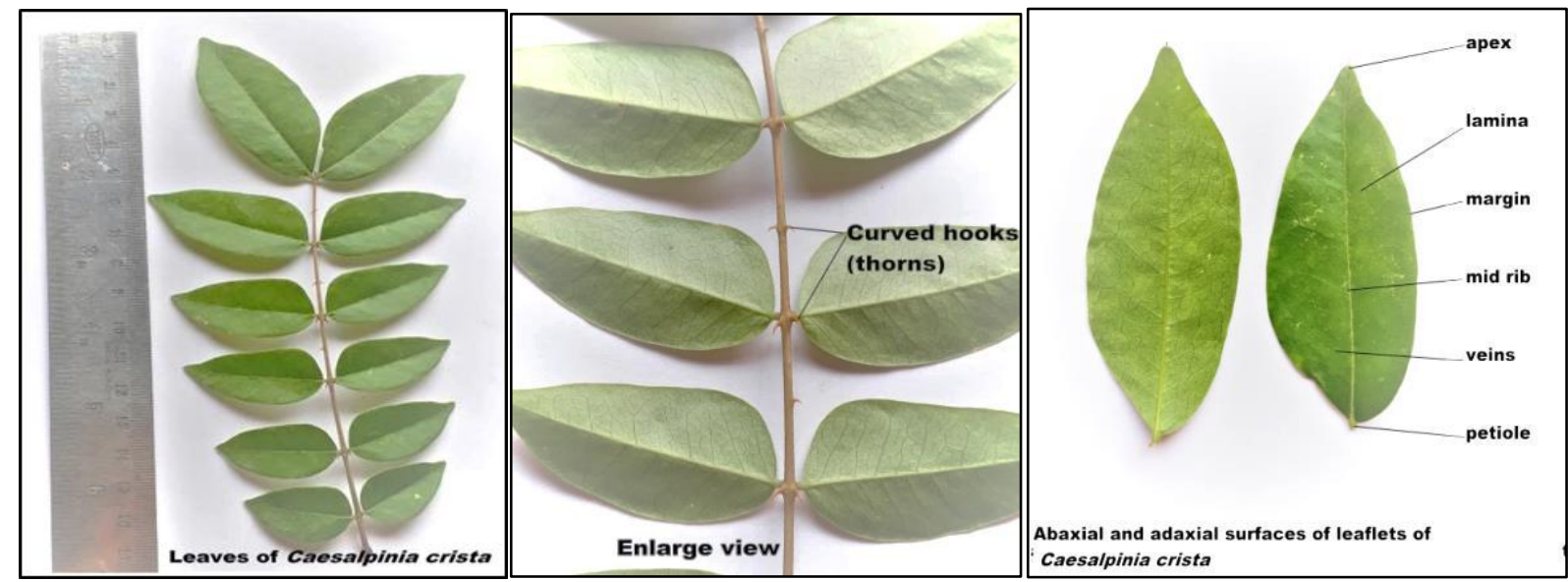

Figure1. Macro-morphology of leaves of C. crista (adaxial surface and abaxial surface) 

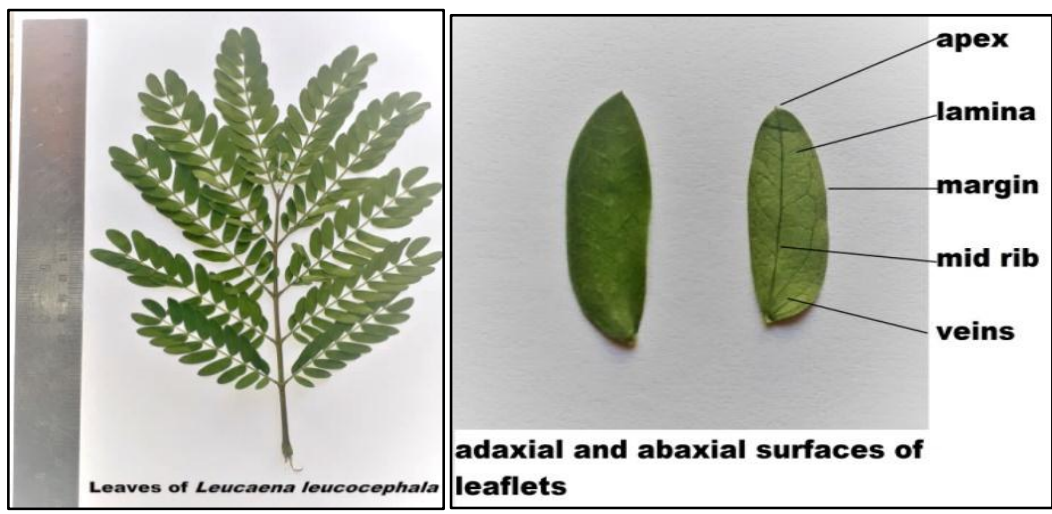

Figure2. Macro-morphology of leaves of L. leucocephala (adaxial surface and abaxial surface)

Table1. Organoleptic Parameters

\begin{tabular}{|l|l|l|l|}
\hline S.N. & Parameters & Caesalpinia crista (Linn.) & Leucaena leucocephala (Lam.) \\
\hline $\mathbf{1 .}$ & Leaf type & Pinnately Compound/Paripinnate & Pinnately Compound/Paripinnate \\
\hline $\mathbf{2 .}$ & Glands at leaf base & Absent & Present \\
\hline $\mathbf{3 .}$ & Phyllotaxy of leaflets & Alternate/Opposite/Superposed & Alternate/Opposite/Superposed \\
\hline $\mathbf{4 .}$ & Outgrowths at base of leaf-lets & Curved hooks & Interpetiolar stipules \\
\hline $\mathbf{5 .}$ & Colour of leaf-let (adaxial surface) & Dark green & Dark green \\
\hline $\mathbf{6 .}$ & Colour of leaf-let (abaxial surface) & Light green & Light green \\
\hline $\mathbf{7 .}$ & Petiole (of each leaf-let) & Petiolate & Absent/ sessile \\
\hline $\mathbf{8 .}$ & Number of leaflet & $12-16$ & $18-24$ \\
\hline $\mathbf{9 .}$ & Composition of lamina (of each leaf-let) & & \\
\hline a. & Shape & Elliptical & Elliptical \\
\hline b. & Dimension $\left(l^{*}\right.$ b) & $14.24 \pm 0.24$ & $0.86 \pm 0.04$ \\
\hline c. & Margin & Entire with pilose trichomes & Entire \\
\hline d. & Apex & Acute & Apiculate \\
\hline e. & Surface appearance & Glabrous & Glabrous \\
\hline f. & Venation & Unicostate & Unicostate \\
\hline
\end{tabular}

\subsection{Micromorphology}

The results of the micromorphology reveal that the leaflets of $\boldsymbol{C}$. crista have apple type stomata (stomata present only on the lower surface). The epidermal peeling of abaxial surface of the leaflet reveals the presence of large, polygonal, thin walled epidermal cells and paracytic stomata which are surrounded by 2 or 3 subsidiary cells on either side of the guard cells and are parallel to stomata. The peeling of adaxial surface of leaf-lets consists of small polygonal thin walled epidermal cells. Trichomes are absent on both surfaces but some pilose unicellular trichomes with glandular base are present on leaf margin.
The results of the micromorphology reveal that the leaf-lets of $\boldsymbol{L}$. leucocephala consist of potato type stomata (more stomata are present on lower surface and less on its upper surface). The epidermal peeling of both the abaxial and adaxial surfaces of leaf-lets, exhibits the presence of large, polygonal, thin walled epidermal cells and paracytic stomata. There were 2 or 3 subsidiary cells on either side of the guard cells and which are parallel to the stomata. Trichomes are absent on both the surfaces. 

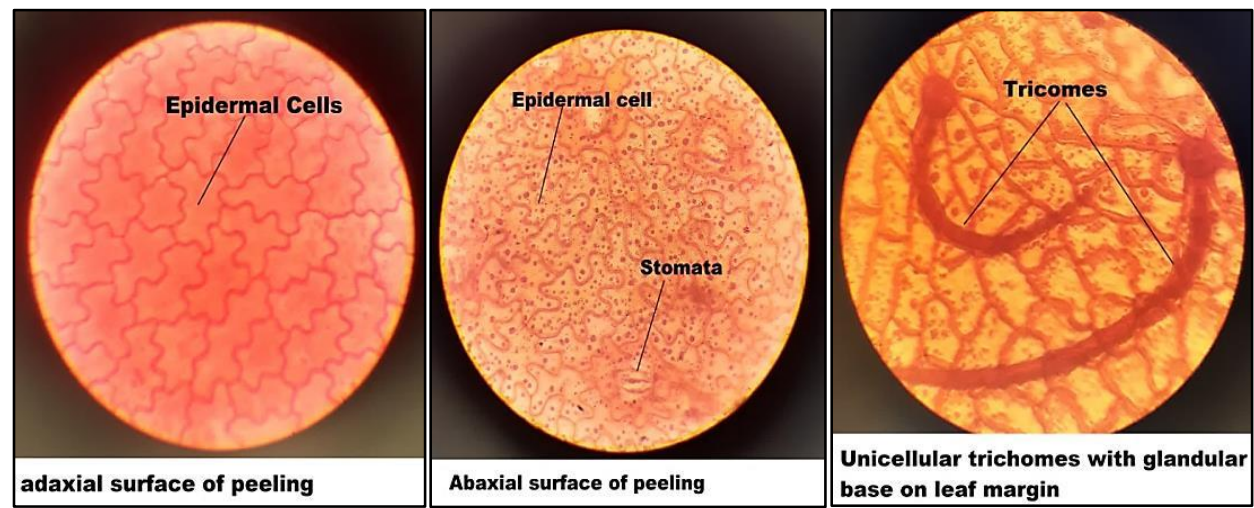

Figure 3: Micromorphology of leaves of C. crista (adaxial surface and abaxial surface)
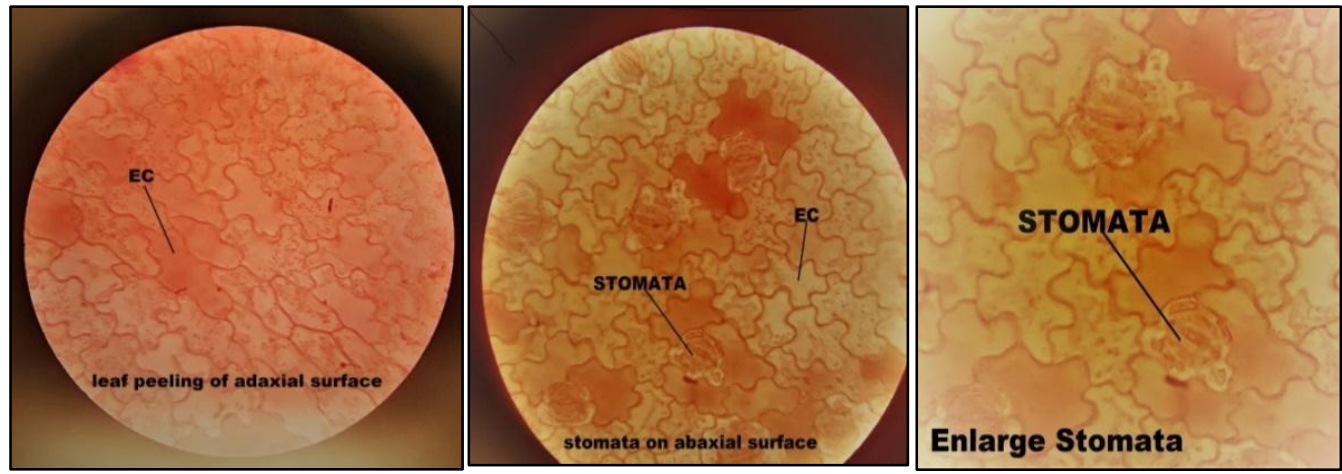

Figure4. Micromorphology of leaves of L. leucocephala (adaxial surface and abaxial surface)

\subsection{Quantitative microscopy}

The quantitative analysis shows that the number of epidermal cells is $52.5 \pm 0.63$ and $54.7 \pm 0.8$, stomata number is 0 and $4.3 \pm 0.22$, stomata index is 0 and $7.26 \pm 0.33$ for adaxial and abaxial surfaces respectively for the leaf-lets of C. crista.
The results of quantitative analysis of leaf-lets of $\boldsymbol{L}$. leucocephala reveals that the number of epidermal cells is $45.7 \pm 0.31$ and $61.6 \pm 0.8$, stomata number is $0.3 \pm 0.1$ and $6.1 \pm 0.6$, stomata index is $0.64 \pm 0.34$ and $8.95 \pm 0.9$ for adaxial and abaxial surfaces respectively.

Table2. Quantitative Observations

\begin{tabular}{|l|l|l|l|}
\hline S.N. & Parameters & Caesalpinia crista (Linn.) & Leucaena leucocephala $($ Lam.) \\
\hline 1. & Stomata number on adaxial surface & 0 & $0.3 \pm 0.1$ \\
\hline $\mathbf{2 .}$ & Stomata number on abaxial surface & $4.3 \pm 0.22$ & $6.1 \pm 0.6$ \\
\hline 3. & Epidermal cell number on adaxial surface & $52.5 \pm 0.63$ & $45.7 \pm 0.31$ \\
\hline $\mathbf{4 .}$ & Epidermal cell number on abaxial surface & $54.7 \pm 0.8$ & $61.6 \pm 0.8$ \\
\hline $\mathbf{5 .}$ & Stomatal index on adaxial surface & 0 & $0.64 \pm 0.34$ \\
\hline $\mathbf{6 .}$ & Stomatal index on abaxial surface & $7.26 \pm 0.33$ & $8.95 \pm 0.9$ \\
\hline
\end{tabular}




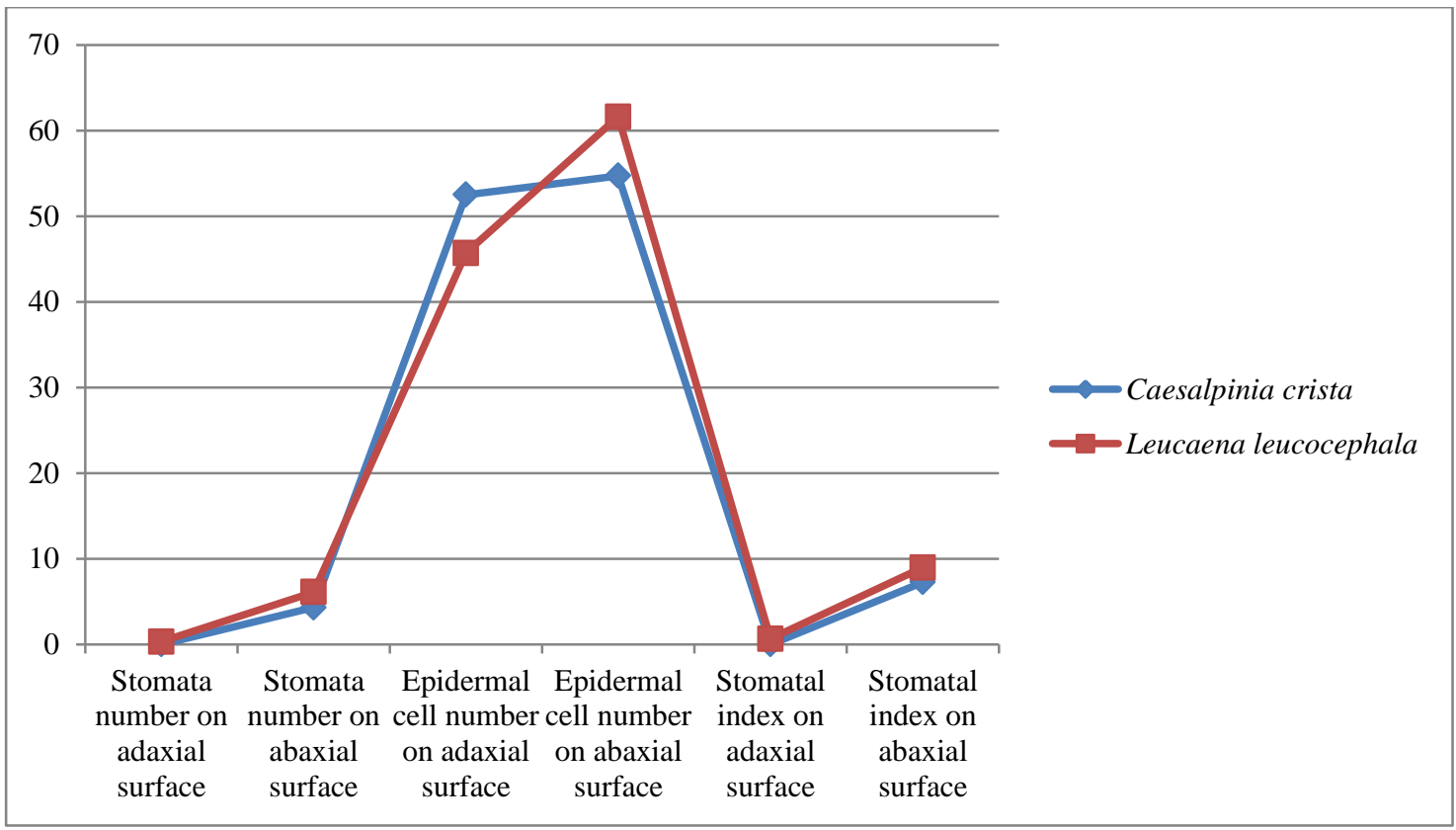

Figure5. Graphical presentation of mean values of Parameters

\section{CONCLUSION}

The pharmacognostic parameters in terms of macro and micro-morphological characters of the leaves of $\boldsymbol{C}$. crista and $\boldsymbol{L}$. leucocephala might be useful in identification,

\section{REFERENCES}

[1]. P. Pradhan, L. Joseph, M. George, N. Kaushik, R. Chulet, "Pharmacognostic, Phytochemical \& Quantitative Investigation of Saraca asoca leaves", Journal of Pharmacy Research, Vol. 3, Issue 4, pp. 776-780, 2010,

[2]. K. Annan, R.A. Dickson, I.K. Amponsah, J. Jato, I.K. Nooni, "Pharmacognostic Evaluation and Physicochemical Analysis of Paullinia pinnata L. (Sapindaceae)", Journal of Pharmacognosy and Phytochemistry, Vol. 2, Issue 2, pp . 203208, 2013.

[3]. V. Singh, P.K. Raghav, "Review on pharmacological properties of Caesalpinia bonduc L.", Int. J. Med. Arom. Plants Vol. 2, No. 3, pp. 514-530, 2012.

[4]. M. Dwivedi, P.K. Singh, S. Prakash, R. K. Dubey, S. Tiwari, A. Kumar, L.K. Shukla, "Pharmacognostical and Phytochemical Study on Caesalpinia bonduc.l (LATAKARANJ)An Overview ",World Journal of Pharmaceutical Research Vol. 5, Issue 2, pp.1512-1520, 2016.

[5]. K. Pramod, Raghav , V. Singh, "Comparison of The Physicochemical Analysis and Phytochemical Screening of Leaves and Seeds of Katkaranj (Ceasalpinia bonduc) ". International Journal of Biological \& Pharmaceutical Research. Vol. 5, Issue 4, pp. 313-322, 2014.

[6]. K.R. Kirtikar, B.D. Basu, “Indian Medicinal Plants”, 2nd ed., B.S.M.P. Singh and Periodical Experts, Dehra Dun, India, Vol. 2, pp. 842-845, 2003.

[7]. R. Deivasigamani, "Phytochemical analysis of Leucaena leucocephala on various extracts, The Journal of Phytopharmacology", Vol. 7, Issue 6, pp. 480-482, 2018. standardization and authentication of crude drug. The various parameter studied during the present investigation will also be helpful in quality assessment and detection of adulterants in the herbal material used by various pharmaceutical companies.

[8]. A.Z.M. Salem, M.Z.M. Salem, M. Gonzalez-Ronquillo, L.M. Camacho, M. Cipriano, "Major chemical constituents of Leucaena leucocephala and Salix babylonica leaf extracts", Journal of Tropical Agriculture Vol. 49 (1-2), pp. 95-98, 2011.

[9]. F.A. Awe, A.O. Giwa-Ajeniya, A.A. Akinyemi, G.N.O. Ezeri, "Phytochemical Analysis of Acalypha wilkesiana, Leucaena leucocephala, Pepperomia pellucida And Sena alata Leaves ”. The International Journal Of Engineering And Science (IJES) Vol. 2, Issue 9 ,pp. 41-44, 2013.

[10]. H.Y. Mohan Ram, V.L. Nayyar, a leaf clearing technique with a wide range of applications. Proc. Indian Acad. Sci. Vol. 87B, Issue 5, pp. 125-127, 1978.

[11]. W.C. Evans, "In: Trease and Evan's Pharmacognosy", 14th edition. Evans, W. C. and Evans, D. (eds.), W.B. Saunders, London, New York, UK, pp. 576-578, 1997.

[12].C.K. Kokate, “In: Practical Pharmacognosy", Vallabh Prakashan, India , pp. 107-111, 115-121, 2001.

[13]. C.K Kokate, A.P. Purohit, S.B. Gokhale, "In: Pharmacognosy", Nirali Prakashan, India, pp. 100, 336, 2003.

[14]. G. Shah, U.S. Baghel, "Pharmacognostic standardization of the leaf of melaleuca alternifolia (maiden \& betche) cheel”, Afr J Tradit Complement Altern Med, Vol. 14, Issue 3, pp. 1-11, 2017.

[15]. V.K. Kumar, R. Rajlakshmi, “Anatomy and stomatal micromorphology of Psophocarpus tetragonolobus (L.)DC.(Winged Bean)", International Journal of Scientific Research in Biological Sciences, Vol. 6, Issue 1, pp. 233-239, 2019.

Author's profile 
Ms. Radhika Rani is a research scholar, Department of Botany, Samrat Prithviraj Chauhan Government College, Ajmer, Rajasthan, India. She has completed M.Sc. Degree in Botany from Samrat Prithviraj Chauhan Government College, Ajmer, Rajasthan, India.
Dr. Tahira Begum is currently working as Associate Professor, Department of Botany, Samrat Prithviraj Chauhan Government College, Ajmer, Rajasthan, India. She has been awarded with a Ph.D. Degree in Botany from Maharshi Dayanand Saraswati University, Ajmer, Rajasthan, India. 